\title{
Web visibility of Romanian universities - an analysis based on website analytics and social media data
}

\section{Mirică, Andreea ${ }^{\text {a }}$; Toma, Iulia Elena ${ }^{\text {b }}$}

${ }^{a}$ Department of Statistics and Econometrics, Bucharest University of Economic Studies, Romania, ${ }^{a}$ Department of Statistics and Econometrics, Bucharest University of Economic Studies, Romania.

\begin{abstract}
There are many aspects that influence the importance of a university. Among these, web visibility is taking advantage of available technology, focusing on the benefits of internet and social media. This paper provides an analysis of the Romanian public and private universities websites, using alexa.com, a tool for website traffic analysis. Moreover, the official social media accounts of universities (Facebook, Twitter, Google+, Flickr, YouTube and Instagram) were analysed, collecting several data such as: the number of likes and followers, the number of subscribers and the number of posts. The analysis was performed using ANOVA and Nonparametric Test for the presence via websites and Spearman and Pearson correlation to assess the correlation between social media and website traffic. In general, public universities from Romania have more visibility and a higher number of links to their websites compared to private ones. Based on the fact that Facebook and site content are often related, it should be noted that activity on Facebook may improve website rankings for Romanian universities.
\end{abstract}

Keywords: web visibility; social media; university; ANOVA; correlation. 


\section{Introduction}

Thelwall (2002) argues that analysing the impact a university website produces is equally important as analysing the impact of scientific research through citations, although the impact is not the same as stated by Jeyshankar and Ramesh Babu (2009). Moreover, Thelwall and Harries (2003) conclude that there is a strong connection between web presence of an university and research quality. Also, McNutt and Marchildon (2009) show that web presence is a crucial factor in increasing internationalisation. Furthermore, according to Kretschmer and Aguillo (2004), web visibility is essential in enhancing transnational collaborations in research.

In this context, this article aims to analyse the web visibility of Romanian universities from two perspectives: website traffic analytics and social media presence. The research is particularly important for university management in this country.

\section{Data}

A list of Romanian universities that are authorised for functioning or fully accredited is provided by The Romanian Agency for Quality Assurance in Higher Education at the following link http://www.aracis.ro/en/eval-results/institutional-evaluations/ (accessed 30 January 2018). For each university the website was analysed using the facilities provided by alexa.com, one of the most powerful tools for website traffic analysis. It should be noted that alexa.com only measures traffic for domains (https://support.alexa.com/hc/enus/articles/200461930-Subdomains-Where-do-visitors-go accessed 30 January 2018). Several indicators were collected, as follows: Global traffic rank; Traffic rank in country; Bounce rate; Daily Page views per Visitor; Daily Time on Site; The number of sites linking in; Percentage of visitors from Romania.

Next, for each university the official social media accounts were analysed: number of likes and number of followers (for Facebook); number of likes, number of followers and number of tweets (for Twitter); number of followers (for Google+ and Flickr respectively); number of subscribers (for YouTube); number of posts and number of followers (for Instagram). As one can observe professional networks such as LinkedIn or Research Gate were not included in the analysis. All data were collected on $5^{\text {th }}$ January 2018.

\section{Methods}

In order to perform the analysis, certain records were first eliminated. Universities that do not have any social media account ( 5 cases) were not included as the influence of social media on website traffic can't be measured. Universities who do not have a website (3 
cases) could not be included either. Universities whose website domain were not registered in Romania (4 cases) were not included as traffic rank in Romania can't be calculated. In the end, 82 universities were analysed.

First, web presence via website and social media presence of Romanian universities are analysed separately, using ANOVA for interval-ratio indicators with enough cases and Nonparametric Test for Median for ordinal indicators. Second, an analysis on how social media is correlated to website traffic will be conducted. For this reason, correlation coefficients between variables describing website traffic and social media activity will be used.

\section{Results}

Table 1 shows the number of universities reporting for each social media indicator, out of 55 public universities and 27 private universities. As one can observe, almost all the universities have reported Facebook activity while only $34.1 \%$ have reported Twitter activity in terms of tweets and followers. It should be noted that only $12.2 \%$ have reported likes on Twitter. Moreover, the results are similar for public and private universities.

Table 1. Number of universities reporting for each social media indicator

\begin{tabular}{|l|l|l|l|l|l|l|}
\hline & Total & Public & Private & $\begin{array}{l}\text { As \% of } \\
\text { total }\end{array}$ & $\begin{array}{l}\text { As \% of } \\
\text { public }\end{array}$ & $\begin{array}{l}\text { As \% of } \\
\text { private }\end{array}$ \\
\hline Twitter_tweets & 28 & 19 & 9 & 34.1 & 34.5 & 33.3 \\
\hline Twitter_followers & 28 & 19 & 9 & 34.1 & 34.5 & 33.3 \\
\hline Twitter_likes & 10 & 7 & 3 & 12.2 & 12.7 & 11.1 \\
\hline Facebook_likes & 80 & 55 & 25 & 97.6 & 100.0 & 92.6 \\
\hline Facebook_followers & 80 & 55 & 25 & 97.6 & 100.0 & 92.6 \\
\hline Youtube_subscribers & 34 & 20 & 14 & 41.5 & 36.4 & 51.9 \\
\hline Google_followers & 6 & 3 & 3 & 7.3 & 5.5 & 11.1 \\
\hline Flick_followers & 1 & 0 & 1 & 1.2 & 0.0 & 3.7 \\
\hline Instagram_posts & 2 & 2 & 0 & 2.4 & 3.6 & 0.0 \\
\hline Instagram_followeres & 2 & 2 & 0 & 2.4 & 3.6 & 0.0 \\
\hline
\end{tabular}

Source: designed by the authors, based on collected data 
Next, the average values for indicators with regard to social media presence as well as results for the ANOVA procedure by type of university, where applicable are presented (table 2). As one can observe, the Levene Test for homogeneity shows that the ANOVA procedure can be applied successfully. Yet, the results following this procedure show no statistical difference between the means.

Table 2. Average values for indicators with regard to social media presence

\begin{tabular}{|l|l|l|l|}
\hline & All universities & Public universities & Private universities \\
\hline Twitter_tweets & 1171 & 1044 & 1437 \\
\hline Twitter_followers & 614 & 583 & 679 \\
\hline Twitter_likes & 202 & 285 & 9 \\
\hline Facebook_likes & 11984 & 13414 & 8838 \\
\hline Facebook_followers & 11893 & 13320 & 8752 \\
\hline Youtube_subscribers & 149 & 155 & 140 \\
\hline Google_followers & 67 & 116 & 18 \\
\hline Flick_followers & 3 & Not applicable & 3 \\
\hline Instagram_posts & 91 & 91 & Not applicable \\
\hline Instagram_followeres & 1278 & 1278 & Not applicable \\
\hline
\end{tabular}

Source: designed by the authors, based on collected data

Table 3 presents the Average values for indicators with regard to web visibility as well as results for the ANOVA procedure by type of university. As one can observe, only Percentage_visitors_from_Romania, Bounce_rate and Daily_time_on_site meet the homogeneity condition for applying the ANOVA procedure. Out of these, the only statistical difference between the means by type of university is observed for Bounce_rate, confirming that public universities have a lower bounce rate compared to private ones. For Daily_pages_per_visitor and Sites_linking_in the Welch test is interpreted. A statistical difference between the means by type of university is observed for Sites_linking_in, confirming that public universities have a higher number of links to their websites compared to private ones. 
Table 3. Average values for indicators with regard to web visibility

\begin{tabular}{|l|l|l|l|}
\hline & $\begin{array}{l}\text { All } \\
\text { universities }\end{array}$ & $\begin{array}{l}\text { Public } \\
\text { universities }\end{array}$ & $\begin{array}{l}\text { Private } \\
\text { universities }\end{array}$ \\
\hline Bounce_rate & 0.59719737 & 0.570236 & 0.66781 \\
\hline Daily_pages_per_visitor & 2.95134146 & 3.054727 & 2.740741 \\
\hline Daily_time_on_site & 177.1125 & 188.9818 & 151 \\
\hline Sites_linking_in & 390.740741 & 524.6296 & 122.963 \\
\hline Percentage_visitors_from_Romania & 0.66485246 & 0.6525 & 0.736222 \\
\hline
\end{tabular}

Source: designed by the authors, based on collected data

Table 4 shows the maximum, minimum and median values for Global Rank and Rank in the country as well as the results for the independent tests for median significance by type of university. As one can observe, there is a statistical difference between the medians by type of university for both variables. This confirms that public universities have more visibility both globally as well as in Romania compared to private ones. 
Table 4. Maximum, minimum and median values for Global Rank and Rank in the country as well as the results for the independent tests for median significance.

\begin{tabular}{|c|c|c|c|c|c|}
\hline & Total & Public & Private & $\begin{array}{l}\text { Independent } \\
\text { test for } \\
\text { median } \\
\text { significance }\end{array}$ & $\begin{array}{l}\text { Independent test } \\
\text { for median result }\end{array}$ \\
\hline $\begin{array}{l}\text { Max of } \\
\text { Global_rank }\end{array}$ & 12215686 & 7597903 & 12215686 & & \\
\hline $\begin{array}{l}\text { Max of } \\
\text { Rank_Romania }\end{array}$ & 55372 & 55372 & 47497 & & \\
\hline $\begin{array}{l}\text { Min of } \\
\text { Global_rank }\end{array}$ & 46134 & 46134 & 325714 & & \\
\hline $\begin{array}{l}\text { Min of } \\
\text { Rank_Romania }\end{array}$ & 464 & 464 & 3965 & & \\
\hline $\begin{array}{l}\text { Median of } \\
\text { Global_rank }\end{array}$ & 681371 & 492059 & 3646646 & 0.000 & $\begin{array}{l}\text { Reject the null } \\
\text { hypothesis (The } \\
\text { medians of } \\
\text { Global_rank are } \\
\text { the same across } \\
\text { categories of Type } \\
\text { _university } \\
\text { (public, private)) }\end{array}$ \\
\hline $\begin{array}{l}\text { Median of } \\
\text { Rank_Romania }\end{array}$ & 9181 & 8401 & 12476 & 0.026 & $\begin{array}{l}\text { Reject the null } \\
\text { hypothesis }\end{array}$ \\
\hline
\end{tabular}

Source: designed by the authors, based on collected data

The next two tables analyse the correlation between certain indicators of website traffic and social media presence on Facebook and Twitter. Interpretations will be made according to Statstutor (2017). As one can observe, there is a weak statistically significant correlation between Daily Page views per Visitor and the number of likes and followers on Facebook respectively. Moreover a moderate correlation can be observed between the number of sites linking in and the number of likes and followers on Facebook respectively.

The results in Table 6 indicate a moderate negative correlation between global rank, rank in the country and the number of likes on Facebook and the number of followers on the same platform respectively. As Facebook and site content are often related, one can conclude that 
activity on Facebook may improve website rankings for Romanian universities. This is not applicable to Twitter.

Table 5. Pearson correlation between certain indicators of website traffic and social media presence.

\begin{tabular}{|c|c|c|c|c|}
\hline & $\begin{array}{l}\text { Facebook } \\
\text { number of } \\
\text { likes }\end{array}$ & $\begin{array}{l}\text { Facebook } \\
\text { number of } \\
\text { followers }\end{array}$ & $\begin{array}{l}\text { Twitter } \\
\text { number of } \\
\text { followers }\end{array}$ & $\begin{array}{l}\text { Twitter } \\
\text { number of } \\
\text { tweets }\end{array}$ \\
\hline Bounce rate & -.225 & -.227 & .053 & .065 \\
\hline $\begin{array}{l}\text { Daily Page views } \\
\text { per Visitor }\end{array}$ & $.246^{*}$ & $.247 *$ & .011 & .089 \\
\hline Daily Time on Site & .191 & .192 & -.002 & .101 \\
\hline $\begin{array}{l}\text { The number of sites } \\
\text { linking in }\end{array}$ & $.572 * *$ & $.569 * *$ & .125 & .342 \\
\hline $\begin{array}{l}\text { Percentage of } \\
\text { visitors from } \\
\text { Romania }\end{array}$ & .082 & .083 & -.115 & -.073 \\
\hline
\end{tabular}

Table 6. Spearman correlation between certain indicators of website traffic (global rank and rank in the country) and social media presence.

\begin{tabular}{llllc}
\hline & $\begin{array}{l}\text { Facebook } \\
\text { number of } \\
\text { likes }\end{array}$ & $\begin{array}{l}\text { Facebook } \\
\text { number of } \\
\text { followers }\end{array}$ & $\begin{array}{l}\text { Twitter number } \\
\text { of followers }\end{array}$ & $\begin{array}{l}\text { Twitter } \\
\text { number of } \\
\text { tweets }\end{array}$ \\
Global rank & $-.591^{* *}$ & $-.593 * *$ & -.284 & -.206 \\
$\begin{array}{l}\text { Traffic rank in the country } \\
\text { Romania) }\end{array}$ & $-.495 * *$ & $-.496 * *$ & -.356 & -.296 \\
\hline **results significant at $1 \%$ level & & & & \\
\hline
\end{tabular}

Source: designed by the authors, based on collected data

\section{Conlusions}

Alguillo (2009) stresses the importance of increasing the web audience in the case of universities and proposes several approaches: electronic journals, raw material publication, 
information resulting from more informal activities, creating open access repositories. Our findings suggest that in the case of Romania, Facebook helps in increasing the web visibility of the universities. Therefore, we suggest creating such repositories and promoting them via Facebook.

The research is a good starting point for university managers in charge of designing communication strategies. Yet, the analysis should be extended to the website and social media content. This analysis should first address language. One interesting finding of Aminpour et al. (2009) who conclude that creating content in English can significantly improve web visibility. Also, our findings suggest that Twitter does not help in increasing web visibility of universities. This may be due to improper use of this social media channel, as Linvill et al. (2012) point out, for only one way communication.

\section{References}

Aguillo, I. (2009). Measuring the institution's footprint in the web. Library Hi Tech, 27(4), 540-556.

Aminpour, F., Kabiri, P., Otroj, Z., \& Keshtkar, A. A. (2009). Webometric analysis of Iranian universities of medical sciences. Scientometrics, 80(1), 253-264.

Jeyshankar, R., \& Ramesh Babu, B. (2009). Websites of universities in Tamil Nadu: a webometric study. Annals of library and information studies, 56(2), 69-79.

Kretschmer, H., \& Aguillo, I. F. (2004). Visibility of collaboration on the Web. Scientometrics, 61(3), 405-426.

Linvill, D. L., McGee, S. E., \& Hicks, L. K. (2012). Colleges' and universities' use of Twitter: A content analysis. Public Relations Review, 38(4), 636-638.

McNutt, K., \& Marchildon, G. (2009). Think tanks and the web: Measuring visibility and influence. Canadian Public Policy, 35(2), 219-236.

Romanian Agency for Quality Assurance in Higher Education. (2018). Retrieved January, 30, 2018, from http://www.aracis.ro/en/eval-results/institutional-evaluations/

Statstutor. (2017). Retrieved February, 5, 2018, from http://www.statstutor.ac.uk/resources/uploaded/spearmans.pdf

Thelwall, M. (2002). The top 100 linked-to pages on UK university web sites: high inlink counts are not usually associated with quality scholarly content. Journal of Information Science, 28(6), 483-491.

Thelwall, M., \& Harries, G. (2003). The connection between the research of a university and counts of links to its web pages: An investigation based upon a classification of the relationships of pages to the research of the host university. Journal of the Association for Information Science and Technology, 54(7), 594-602. 